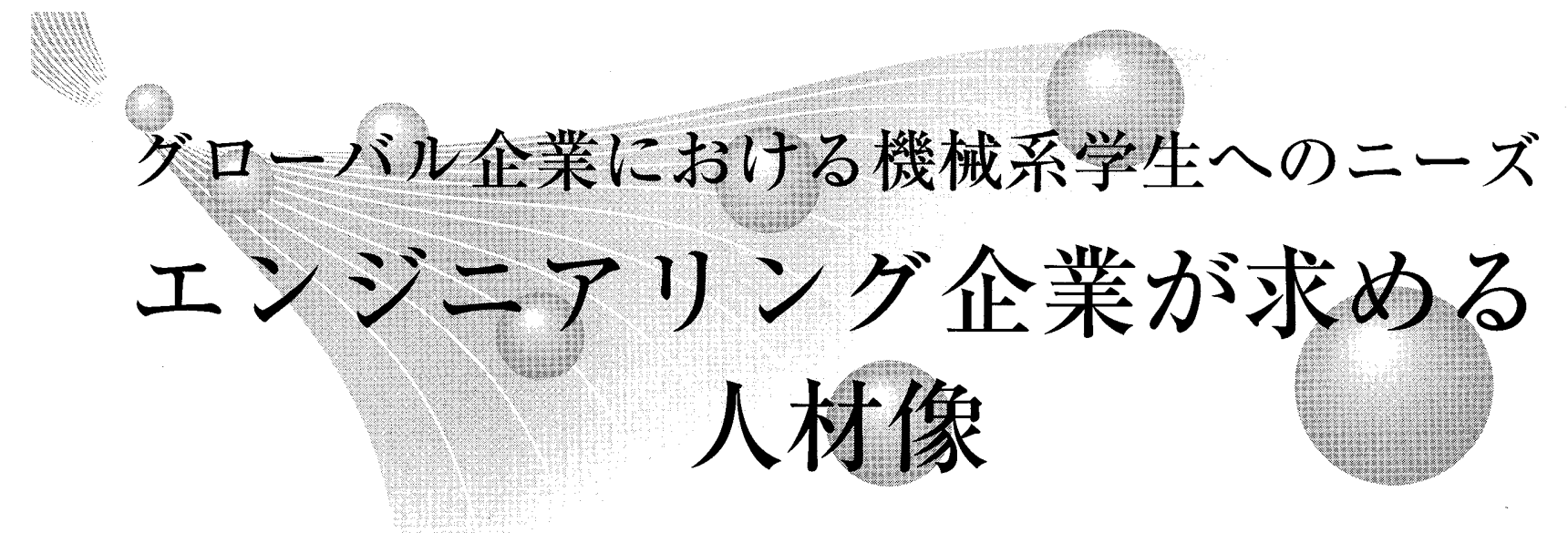

\title{
Engineers' Spirit of Engineering Company
}

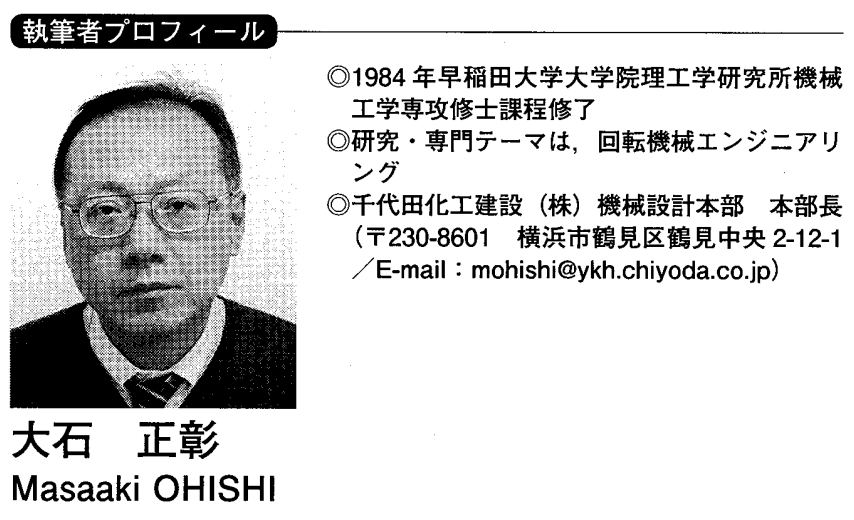

\section{1. はじめに}

千代田化工建設（株）（以下, 当社）は, 戦後の石油精 製事業の再開に備えて産業設備（プラント）専門の高度な 技術会社を作りたいとの熱意から 1948 年に創業した。

その後, 国内石油産業とともに成長, OPEC 誕生の 1959 年には海外営業部署を設置, 1966 年には初の海外プラン 卜建設工事としてサウジアラビア・ジェッダ製油所一期建 設工事を受注し海外展開を進め, 現在では, 石油精製・石 油化学, ガス精製・液化 (LNG) から医薬品, ファイン ケミカル，産業設備などの幅広い分野において，いわゆる EPC (Engineering Procurement $\cdot$ Construction : エンジニア リング・調達・建設）業務としてのプラント建設工事を世 界各地で数多く手がける総合エンジニアリング会社となっ ている. 海外への進出は, 1971 年シンガポール, 1973 年 ヒューストン，1974 年マレーシア，1975 年サウジアラビ アとお客様のお膝元にグループ企業を設立し，いち早く海 外の㧍客様の声に応えられる体制を整えた。

このような体制を整え, 海外でのプラント建設工事を進 めた結果, 2009 年には「サハリン LNG プラント建設工事」 が, 国土交通省よりJAPAN プロジェクト国際賞・国土交 通大臣賞を受賞，また同年，カタールにおける LNG プラ ント建設実績とカタールへの資源開発や地球環境への貢献 が評価され, 政府（経済産業省，国土交通省，文部科学省，
厚生労働省) が主催する第 3 回「ものづくり日本大賞」(海 外展開部門）で部門最高位となる経済産業大臣賞を受賞し ている.

\section{2 エンジニアリング会社に求められ 2. ていること}

エンジニアリング会社は，㧍客様が数十年間使用するプ ラントのエンジニアリング・調達・建設を行い, フル . ターン・キーと呼ばれるスイッチを入れれば直ぐに生産が 開始できる状態に仕上げ，お客様に納入している。

また, お客様の事業計画のフィージビリティ・スタディ, FEED と呼ばれるプラント基本設計業務，さらには，EPC 業務で完成させたプラントの運転・保守までを考慮したプ ラント・ライフサイクル・エンジニアリングも行っている.

これらの業務を遂行するエンジニアリング会社に求めら れることは, プラントのエンジニアリング・調達・建設に 優れていることは当然として，打客様以上にプラントに知 彔していること, プラント安全確保に周知していること, 㧍客様の業界動向に通じていること, 打客様以外の業界動 向についての知見を有していることであり，拈客様にとっ て有益な提案ができる技術的な能力と知見を有しているこ とが不可欠である。そしてさらに大事なことは，打客様が 使用するプラントが産み出す製品の競争力を高く維持する ための，安価なプラントが提供できることである。

エンジニアリング会社が扮客様にとって魅力ある永続的 なパートナであり続けるためには, 先に示すような技術的 な知見と能力に加え，安価なプラントを扮客様に提供でき る能力を有していなければならない.

\section{2. エンジニアリング会社のグローバ 3. リゼーション}

エンジニアリング会社は, エンジニアリング・調達・建 設のそれぞれの業務についてグローバリゼーションを推し 進めることでプラントの価格低減への挑戦を続けている。

このグローバリゼーションについては，従来まで，海外 品の調達, 海外工事会社への建設工事発注というような形 態にとどまっていたが, 現在では, ITインフラの発達に よって海外のどこにいてもコミュニケーションをとること 
が可能となってきて扮り，従来まで日本で行っていたエン ジニアリング業務, 調達業務, 建設業務をも海外に移管し て行うようになってきている。こうすることで，エンジニ アの時間単価, 日本の約 100 ドルに対し,たとえばインド . フィリピンでは約 20 ドルとすることができ，人件費の大 幅な低減が可能となっている.

また, 2000 年頃から, プラント大型化・高価格化に伴い, エンジニアリング会社一社の単独受注ではなく他のエンジ ニアリング会社とジョイント・ベンチャーを組んでプロ ジェクトを共同受注するというケースも増えている。

これは，高価格プラントの受注リスク低減目的だけでな く，各社の得意分野をともに活かすという目的があり，当 社でも, 日本, イギリス, フランス, イタリア,アメリカ, 韓国などのエンジニアリング会社とジョイント・ベン チャーを組んでプロジェクトを遂行している.

\section{4. エンジニアの仕事}

エンジニアリング会社にとっては，プラントのエンジニ アリング・調達・建設を行うことが基本であるので, エン ジニアはそれができるだけの能力を有していることが必須 であることに間違いはない，

すなわち，機械系の人材であれば，俗に言う四力を十分 に理解し適切に使いこなせることが必要である。

しかしながら，実際はどうかといえば，設計ツール・手 法の開発を行う部署に配属される場合であればともかく， 設計手法・手続きを一から考えだすことは敖で，すでに確 立された・決められた計算式・設計ソフトウェアに数值を 入力すれば答えが出てくる場合がほとんどである。また， 担当する業務範囲は限られている場合が多く, 機械系エン ジニアとして四力すべての深い理解は必ずしも必要ではな い.

また，先に述べたとおりのグローバリゼーションを加速 しており，従来まで日本で行っていたエンジニアリング業 務，調達業務，建設業務を定型化して海外に移管して行う ようになってきている.

\section{5. エンジニアにとって大事なこと}

エンジニアリング会社が手掛けるプラントは，扮客様が 数十年使用寸る設備であるから，㧍客様が何を求めている のかを理解してプラントを作ることが非常に重要である.

安全第一はどの怙客様でも共通だが，たとえば，手持ち 資金が潤沢でない敃客様の場合には，運転のしやすさ，プ ラント仕様の高さ，プラントを運転するためにかかる費用 よりも，初期投資額が小さくなることを重視する傾向があ る。また，お客様の経験，たとえば，お客様の他の類似プ ラントでのトラブル経験に基づいた特殊仕様を要求される 場合もある。

このように，お客様に満足いただけるプラントを作るた めには，扮客様が何を求めているかを正しく理解すること が大事になるのだが，どうすれば扮客様が求めていること を正しく理解することができるのであろうか？

まず大前提として英語ができなければ話にならない，そ
して英語ができたとして次は何か？

それは，打客様が何を求めているのかを理解しようとい う気持ちと態度であり, 聞く姿勢ができているということ が必要である。 また，お客様が何を求めているかが理解で きるだけの基本的な工学の知識も不可欠である.

そして，拈客様が望まれているのは，扮客様にとって有 益な提案ができる永続的なパートナなのだから，パートナ として尊敬されるだけの知識, 経験, 能力, 情報を有して いると同時に，エンジニア個人として己の意見を有してい ることが大事になってくる.

すなわち，扮客様に相談してみようと思わせるだけの魅 力あるエンジニアであることが重要となる.

\section{6. おわりに一機械系エンジニアに求 6. めること}

エンジニアリング会社は，グローバリゼーションに遇進 している、しかしながら，現状は，どの会社もいまだ道半 ばであり，手探りしながら正しいやり方を模索し成果を上 げる努力を続けているという状況である。

このグローバリゼーションの観点で考えても，エンジニ アは，まず大前提として，英語ができなければ話にならな い. そして基本的な工学の知識を有してお客様が何を求め ているかを理解でき，招客様に相談してみようと思わせる だけの魅力あるエンジニアであってほしいと思う。

さらに，グローバリゼーションの観点で付け加えれば, 海外の抢客様・同僚とうまく仕事を行い, プラントを完成 させるためには，機械系のエンジニアといえども，日本の 歴史と文化を語れ，日本人にとっての仕事の意味と価値を 語れなければならず，相手の歴史と文化を理解し彼らに とっての仕事の意味と価值に共感できるだけの広い視野を 持つ必要がある。

そして，エンジニアリング会社に身を置く者として機械 系のエンジニアに期待することは，大きくても小さくても 世の中にサムシング・グッド, サムシング・ベターをもた らすのだという気概と意気込みを持って日々を過ごす努力 を忘れないでもらいたいということである.

機械系の学生として四力を理解していることは望ましい ことに違いないが，大学の 4 年間，大学院を含めた 6 年間 で学んだ知識だけで 30 年以上にもわたる社会人生活で起 きるすべてのことをカバーできるわけはない.

今, 勉強が足りない方でも, 勉強の仕方くらいは学んで いると信じている，学ぶに遅すぎるということはない，扔 客様に魅力を感じさせるエンジニアになって世の中のため になる何かをしようという気概と意気込みを持った機械系 エンジニアに期待している.

（原稿受付 2012 年 2 月 21 日） 